\title{
4 \\ Rapid Detection of Bacteria in a Water Distribution System
}

Rolf A Deininger, Ji Young Lee and Jungwon Min

A water distribution system may be contaminated by bacteria through crossconnections, by intrusion of soil water after a pressure loss due to a power blackout, or by the intentional contamination of the system in a bio-terrrorism event. The problem a utility faces is to detect it in a timely fashion, and to take immediate action to correct the problem and at least warn consumers.

Currently approved microbiological methods are all culture based. That is, after filtration the water sample is placed on an agar plate and then incubated at varying temperatures for one to seven days. A determination of the indicator bacteria E. coli takes 24 hours, and the most sensitive test for total bacteria is an HPC count of the colonies growing on R2A agar for three to seven days. These tests are clearly not useful for protection of the consumers in a timely fashion.

We have worked on a rapid test method whereby we capture the bacteria from a water sample on a 0.45 micron filter and then lyse the bacteria. The released adenosine triphosphate (ATP) from the bacteria reacts with added luciferin/luciferase and then light emission takes place that can be measured with a luminometer. The whole procedure takes less than five minutes. The amount of ATP is proportional to the number of bacteria.

To test if a sewage intrusion can be detected, experiments have been conducted in beakers where a small quantity of sewage (secondary effluent of the Ann Arbor Wastewater Treatment Plant (AAWWTP) was added to water samples, and the bacterial counts were determined by ATP analysis and the

Deininger, R.A., J. Lee and J. Min. 2005. "Rapid Detection of Bacteria in a Water Distribution System." Journal of Water Management Modeling R223-04. doi: 10.14796/JWMM.R223-04.

(C) CHI 2005 www.chijournal.org ISSN: 2292-6062 (Formerly in Effective Modeling of Urban Water Systems. ISBN: 0-9736716-0-2) 
traditional culture methods. Three types of water were used: (i) drinking water that is chloraminated, (ii) water that is chlorinated, and (iii) water that carries a chlorine dioxide residual. As expected, chlorine dioxide will eliminate the bacteria very fast, followed by the chlorinated and chloraminated waters. In all cases the contamination of water can be clearly shown through the ATP analysis in less than five minutes. The test can be automated so that a nearly continuous monitoring is possible.

\subsection{Introduction}

Water distribution systems may be contaminated with bacteria through crossconnections, by intrusion of soil water when pressure is lost and there are cracks in the pipes, or by the intentional introduction of pathogenic organisms in a terrorist event. Prevention of cross-connections is a problem that has been studied over the years and can be largely eliminated through a proper sanitary survey. In the case of a prolonged blackout, as happened in 2003 in the midwest through northeast of the US and Canada, pressure is lost in the pipes if there is no power backup. Where there are small cracks or fissures, or leaking seals, soil water may intrude into the pipes. If there are leaking sewers in the immediate neighborhood of the water mains, wastewater may intrude and be carried in the mains when pressure and flow is restored. A deliberate contamination of a water supply system can occur if terrorists gain access to water reservoirs, or by injection into the pipes by overcoming the pressure of the system. There are other scenarios, and even back in 1970 the World Health Organization recognized this (World Health Organization, 1970), as did the American Water Works Association in 1984 (American Water Works Association, 1984). Hospital emergency room records show that an unusual high number of people get ill and seek medical attention, e.g. Walkerton, ON, a case of unintentional contamination (http://www.walkertoninquiry.com).

In order to prevent exposure to contaminated water, water samples are regularly examined for their microbial water quality. The problem is that the current culture-based test methods for bacteria take from one to seven days since they require an incubation period, a situation which has not changed much for over 100 years. Worse yet, tests for E. coli do not indicate that the pathogen E.coli O157:H7 is present, since the latter do not grow on the traditional media.

What is needed is a method that estimates the number of bacteria in a water sample in minutes, not days. For the past five years we have worked on such a method that basically concentrates bacteria in a water sample onto a

filter. Rather than providing the bacteria with nutrients, and growing them in an incubator, and then counting the grown colonies in a traditional method, 
our method lyses the bacteria. The bacteria will release their ATP which reacts with added luciferine/luciferase and produces light. The light emission is quantified with a luminometer, and is proportional to the ATP, which in turn is proportional to the number of bacteria present in water (Lee and Deininger, 1999; Deininger and Lee, 2001). Higher light emission indicates higher bacterial levels in a sample. The bacterial levels in drinking water estimated with ATP assay correlated very well with the bacterial counts measured with the R2A plate count method (Lee and Deininger, 1999; Deininger and Lee, 2001). If the tests show elevated levels of bacteria where a glass of water can carry an infectious dose, it is possible to identify the bacteria using an immunomagnetic separation followed by ATP assay for a specific capture and quantification, respectively (Lee and Deininger, 2004).

\subsection{Materials and Methods}

The basic principle of the analysis is to quantify the ATP contained in the bacterial cells. This is done by lysing the cells with a bacterial releasing agent, and the released ATP reacts with luciferine/luciferase to produce light that is measured in a luminometer. Figure 4.1 shows the chain of reactions in simplified form (Qureshi and Patel, 1976).

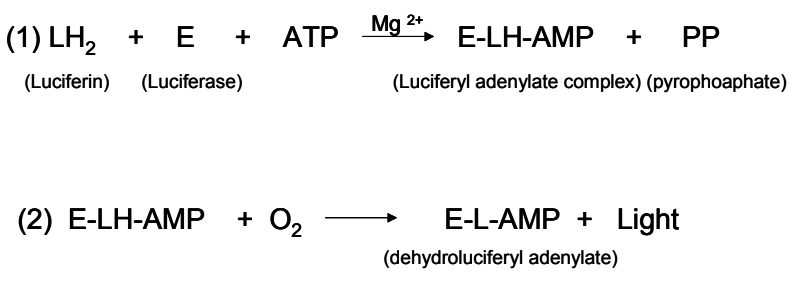

Figure 4.1 Reaction between ATP and luciferine-luciferase to produce light that is measured in a luminometer.

The detailed procedure of ATP assay is described in Lee \& Deininger (1999) and Deininger \& Lee (2001). Briefly, a certain volume of water sample (50$500 \mu \mathrm{l})$ was transferred into a Filtravette TM [New Horizons Diagostics (NHD), Columbia, Maryland, USA], which is a combination of cuvette and a filter with a pore size of $0.45 \mu \mathrm{m}$. Gentle air pressure was used to filter it out. Somatic cell releasing agent (NHD, Columbia, Maryland, USA) was used according to the manufacturer's instructions to lyse all nonbacterial cells and release ATP. Air pressure was used to remove the nonbacterial ATP through the filter. At this stage, the bacteria remain on the surface of the filter and then 
$50 \mu \mathrm{l}$ of bacterial releasing agent (NHD, Columbia, Maryland, USA) was added to lyse bacterial cells for one minute. The released bacterial ATP was mixed with $50 \mu 1$ of luciferin-luciferease (NHD, Columbia, Maryland, USA) and the light emission was measured with a luminometer. The unit is relative light unit (RLU) and the result was expressed as RLU/ml by dividing the RLU values by the volume of the filtered water. The activity of luciferinluciferase is checked with ATP standard solution (Sigma, St. Louis, Missouri, USA).

Figure 4.2 shows two luminometers that have been used in our studies (Turner BioSystems, Sunnyvale, CA and New Horizons Diagnostic, Columbia, MD).

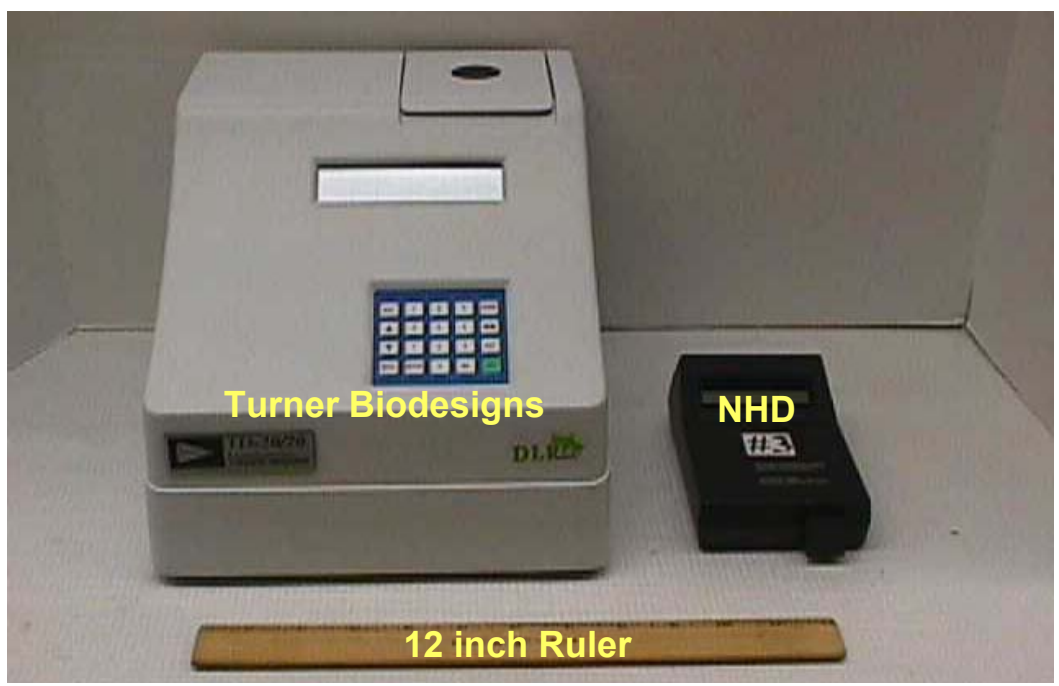

Figure 4.2 Two luminometers used in our studies (Turner BioSystems, Sunnyvale, CA and New Horizons Diagnostic, Columbia, MD).

The two luminometers work quite well and have similar sensitivity, but the second smaller luminometer is ideal for field applications. Essentially necessary equipment for the analysis fits onto a clipboard (Figure 4.3).

The experiments for this chapter were done in the laboratory. Beakers with $500 \mathrm{ml}$ of water were placed on magnetic stirrer platforms and $5 \mathrm{ml}$ of secondary effluent from the Ann Arbor wastewater treatment plant were added. Thus the beakers had water with $1 \%(\mathrm{v} / \mathrm{v})$ sewage in it and the water was gently agitated.

The tests were performed with three drinking waters that carried different disinfectants: chloramine, chlorine, and chlorine dioxide. The water samples were from three different public water supply systems in the southeastern part 
of Michigan. The initial ATP levels of the bacteria in the original water samples before the addition of sewage were analyzed. Immediately after the addition of the wastewater, the water sample was analyzed again for its ATP content. The ATP analyses were repeated during one hour. In the experiments the increase in ATP due to the addition of the sewage was two to three orders of magnitude. It is quite significant and even smaller additions, such as $0.1 \%$ wastewater, can easily be detected.

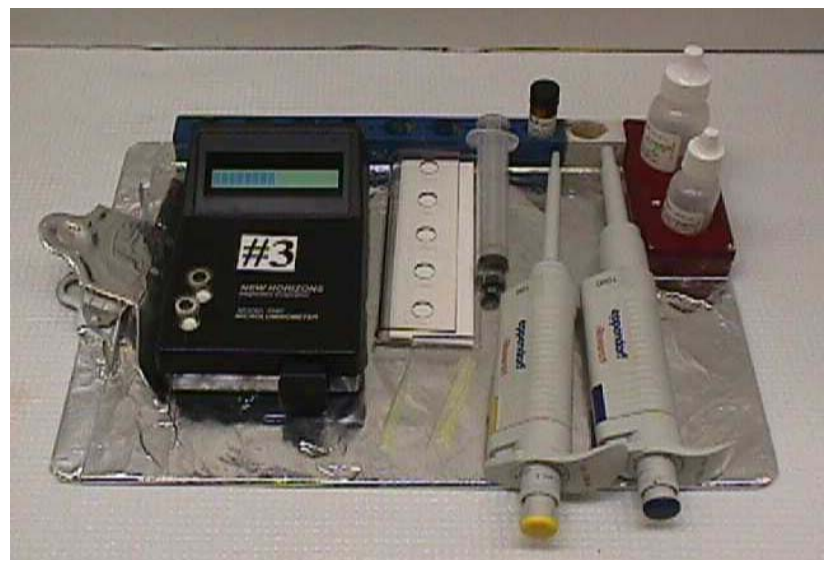

Figure 4.3 All supplies and equipment fit on a clipboard.

\subsection{Results and Discussion}

After the water samples were added with sewage, the increased levels of bacteria were measured at $0 \mathrm{sec}, 1,5,10,20,40$ and $60 \mathrm{~min}$. The background levels of bacteria in water samples before addition of wastewater were measured. Figure 4.5 shows the bacterial levels in water samples with different types of disinfectant. It shows that the \% of remaining bacterial contamination as the time passes on. It also indicates the effectiveness of the different disinfectants. Chloramine is the least effective disinfectant among the three tested disinfectants. Chlorine is more effective, but the chlorine dioxide is the strongest, fastest and most effective disinfectant. Within one minute after the addition of the sewage, $78 \%$ of the ATP level due to the addition of the sewage was removed in the sample with chlorine dioxide. Thus, the result of the fate of contaminated bacteria in drinking water agrees well with the fact of the efficiency of the three different types of disinfectants. Only ozone would be stronger and faster, but it is used as a primary disinfectant at a water treatment plant, and in this study the focus was the 
effectiveness of disinfectants in the event of the contamination of public water supply. After an hour, 99.4\% (chlorine dioxide), $98.3 \%$ (chlorine) and $77.2 \%$ (chloramines) of the bacterial contamination due to the addition of the sewage was removed, respectively. Thus, it implies that the importance of the continuous maintaining of recommended disinfectant level in water distribution system in the events of intentional and accidental contamination.

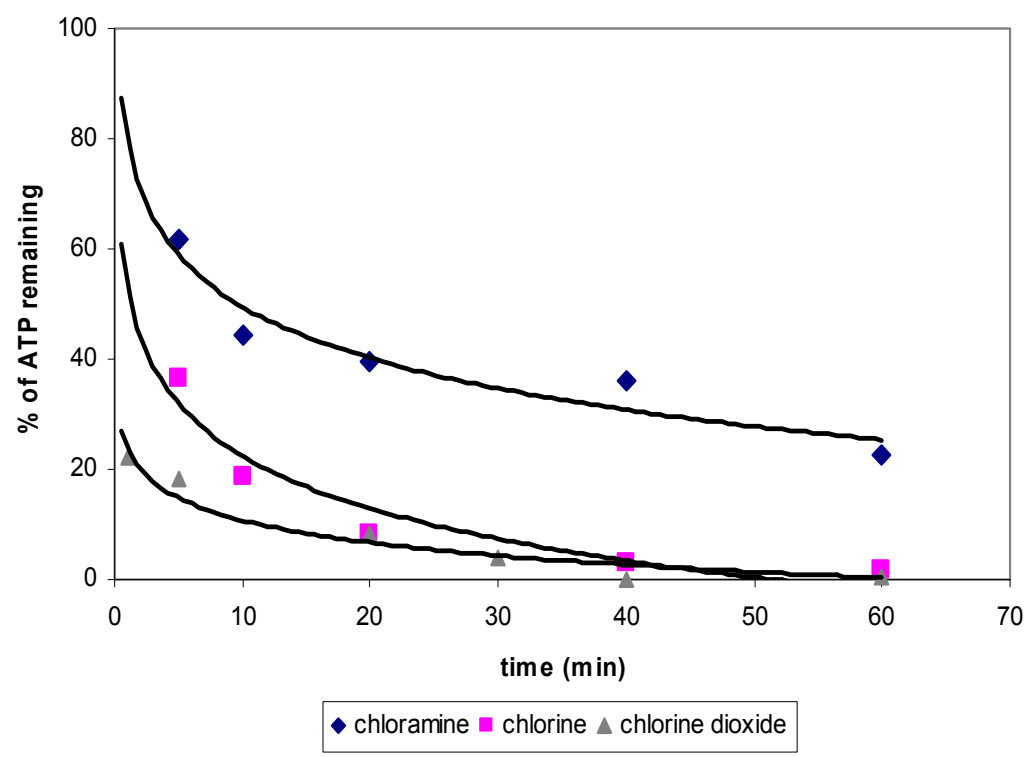

Figure $4.4 \%$ bacteria remaining determined by ATP assay in sewagecontaminated drinking water with three different types of disinfectants.

\subsection{Conclusions}

The increased level of bacteria in a drinking water sample which is contaminated by sewage can be detected in near real time, within minutes, using an ATP assay. The ATP assay does not identify the type of bacteria, nor its contamination source (e.g. cross-connection, intrusion of soil, deliberate introduction of bioterrorism agent). It provides a fast, quantitative measure of bacterial level in drinking water. This study clearly shows the difference in the effectiveness between types of disinfectant. Given enough time even a less effective disinfectant will destroy the bacteria and make water safe again. Thus, for the protection of our water supplies it is essential to carry a disinfectant residual at all time and all places. 


\section{References}

American Water Works Association. 1984. Emergency Planning for Water Utility Management. Appendix A. The Threat from Addition of Chemical and Biological Agents to a Municipal Water Supply. M19. pp 55-64.

APHA, AWWA, WEF, 1998. Standard Methods for the Examination of Water and Wastewater, 20th edition.

Deininger, R.A. and JY. Lee. 2001. Rapid Determination of Bacteria in Drinking Water Using an ATP Assay. Field Analytical Chemistry and Technology. 5:4:185-189.

World Health Organization. 1970. Health Aspects of Chemical and Biological Weapons. Annex 5. Sabotage of Water Supplies pp. 113-120.

Lee, JY. and R.A. Deininger. 1999. A Rapid Method for Detecting Bacteria in Drinking Water. Journal of Rapid Methods and Automation in Microbiology. 7:2:135-145.

Lee, JY. and R.A. Deininger. 2004. Detection of E.coli in beach water within $1 \mathrm{hr}$ using immunomagnetic separation and ATP Bioluminiscence. Luminescence. 19:31-36.

Qureshi, A.A. and J. Patel. 1976. ATP levels in microbial cultures and a review of the ATP biomass estimation technique. Scientific Series No.63. Canada Center for Inland Waters. Burlington, Ontario.

[Online] Available at http://www.walkertoninquiry.com

Turner BioSystems Application Note. A TD-20/20 Luminometer method for ATP Measurements. Sunnyvale, California. 
